\title{
FLOODS EVOLUTION IN THE MEDITERRANEAN REGION IN A CONTEXT OF CLIMATE AND ENVIRONMENTAL CHANGE
}

\author{
MARÍA CARMEN LLASAT \\ GAMA, Meteorology Research Group. Department of Applied Physics, \\ University of Barcelona, Barcelona, Spain.
}

\begin{abstract}
Floods are the most important risk in the Mediterranean region, both due to their frequency and impact. Studies of historical floods show flood-rich periods that could be associated with climate causes, but there is also a certain growing trend as a result of changes in land use and increased vulnerability. If climate scenarios point to an increase in the torrentiality of precipitation, with longer dry periods and more intense rainfall, there is still a high level of uncertainty in their impact in floods. This paper addresses this issue, also considering the complex role of changes to hazards, vulnerability, exposure and capacity. It presents a synthesis of the state of the art, with particular incidence in the first results of MedECC and the most recent bibliography on floods trend. Conclusions show that floods in this region are mainly consequence of flash-flood events. A common positive trend of flash floods in the past probably due to land use changes and the occupation of flood-prone areas has been found (high confidence). The increase of convective precipitation could also justify this positive trend in the most recent period, in some regions (low confidence). Vulnerabilities to water related hazards are expected to be influenced by the future socio-economic conditions at the regional scale (medium confidence). Although expected changes in flood risks are not univocal, nor evenly distributed, flood impacts will increase in the entire Mediterranean region, mainly as a consequence of global changes in the catchments (land use, vulnerability, exposure), joined in the Northern part of the basin to the increase of heavy rainfalls (medium confidence).
\end{abstract}

\section{Evolución de las inundaciones en la región mediterránea en un contexto de cambio climático $y$ ambiental}

RESUMEN. Las inundaciones son el mayor riesgo de la región mediterránea debido tanto a su frecuencia como a su impacto. Estudios de inundaciones históricas ponen de manifiesto que los periodos con un mayor número de inundaciones podrían estar asociados a causas climáticas, pero hay también una cierta tendencia a vincularlos a cambios en los usos del suelo y a un incremento de la vulnerabilidad. Si los escenarios climáticos apuntan a un incremento de la torrencialidad de las precipitaciones, con periodos secos más prolongados y lluvias más intensas, hay todavía un elevado nivel de incertidumbre en su impacto sobre las inundaciones. Este trabajo aborda esta temática, considerando también el complejo papel de los cambios en los riesgos, vulnerabilidad, exposición y capacidad. Se presenta una síntesis del estado del arte, con particular incidencia en los primeros resultados del MedECC y la más reciente bibliografía sobre las tendencias de las inundaciones. Las conclusiones muestran que las inundaciones en esta región son consecuencia principalmente de eventos de flash-flood. Se ha encontrado una tendencia positiva (nivel de confianza alto) de flash-floods en el pasado probablemente debido a cambios de usos del suelo y a la ocupación de espacios proclives a las inundaciones. El incremento de la precipitación convectiva también podría justificar esta tendencia positiva en los tiempos más recientes, especialmente en algunas regiones (confianza baja). Se espera que las vulnerabilidades a los riesgos relacionados con el agua se vean influidas por las condiciones socioeconómicas futuras a escala regional (confianza media). Aunque los cambios esperados en los riesgos de inundaciones no son unívocos, ni están distribuidos uniformemente, los impactos de las inundaciones aumentarán en toda la región mediterránea, principalmente como consecuencia de los cambios globales en las 
cuencas (uso del suelo, vulnerabilidad, exposición) y el incremento de las precipitaciones intensas en el sector norte de la cuenca.

Key words: Floods, flash floods, climate change, natural hazards, Mediterranean region.

Palabras clave: Inundaciones, inundaciones súbitas, cambio climático, riesgos naturales, región mediterránea.

Received: 29 September 2020

Accepted: 17 January 2021

Corresponding author: María Carmen Llasat, GAMA, Meteorology Research Group, Department of Applied Physics, University of Barcelona, Barcelona, Spain. E-mail address: carmell@meteo.ub.edu

\section{Introduction}

Floods are the natural risk with the greatest impact in the world both because of their frequency and the socioeconomic and environmental losses they produce, as in many cases they are linked to other phenomena such as landslides and/or severe weather. Over the 1997-2017 period, floods affected 76 million people in the world (UNDRR, 2020). The recent MEFF database (flood-related fatalities in the Mediterranean basin) shows that between 1980 and 2018, 1809 fatalities were recorded across six Mediterranean regions (Fig. 1); for the whole Mediterranean basin, the mean annual fatality rate is 0.5 fatalities per million inhabitants (Vinet et al., 2019)

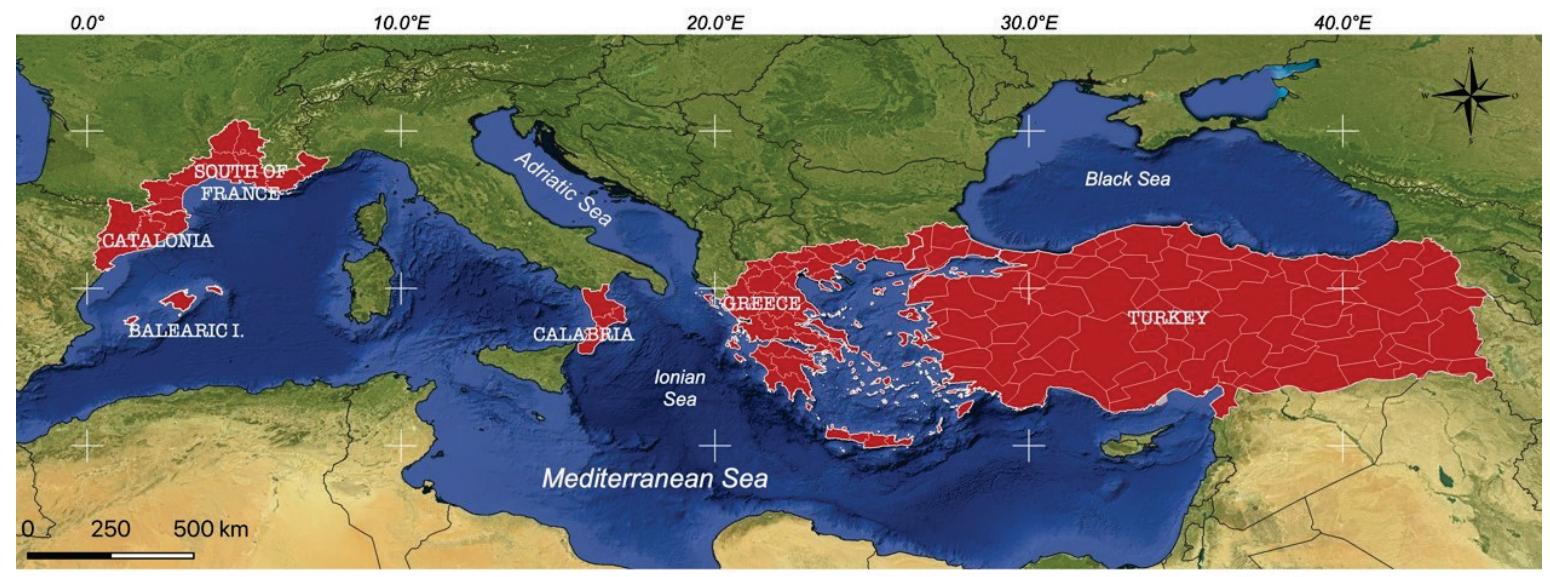

Figure 1. The Mediterranean Region and the countries/regions that are considered in the MEFF v2 database (from Vinet et al., 2019).

There are multiple factors that can influence these impacts, from the characteristics of the rainfall or water flow, to the available means of evacuating the population and raising awareness. For this reason, we need to better understand the main drivers behind flood changes and the links between floods and climate and other factors (Merz et al., 2012). Besides these aspects, which will be presented in the following chapters, the processes are not lineal and there are numerous related elements. For instance, initial soil moisture conditions prior to flood events play a key role in causing floods. An increase in rainfall intensity does not necessarily result in an increased flood risk because the runoff coefficient can be very variable over time and space due to complex interactions between precipitation 
and infiltration processes (Tramblay et al., 2019). The type of soil can also have different sensitivity to changing climatic conditions (Camici et al., 2017; Piras et al., 2016). At the same time, the size and orography of the catchment have a strong influence on changes due to climate and use of soil (Hall et al., 2014).

Floods in the Mediterranean have the added complexity that they normally occur in small, ungauged basins in densely populated areas. This is important both when studying the frequency and magnitude of floods, and to improve early warning systems. In addition, they sometimes occur during periods of drought, and may go unnoticed in frequency studies. This paper focuses on the analysis of trends and anomalies in relation to floods in the Mediterranean. To better contextualize it, the article begins with a presentation of the study area and the factors that may be involved in flood risk. The main conclusions on climatic and environmental changes in the Mediterranean region that might be linked to floods, are shown afterwards. The following sections are devoted to trend and projection analysis, ending with the conclusions.

\section{Study area}

The Mediterranean region has specific characteristics that favour all kind of hydrometeorological risks (Fig.1). It is in an area where subtropical and polar air masses can converge, giving rise to severe weather and heavy rainfall. For instance, Insua-Costa et al. (2019) have demonstrated that the precipitable water mass during the October and November 1982 floods were mainly from the subtropical Atlantic and Western Mediterranean. In addition, the Mediterranean is a warm and almost closed sea, surrounded by an orography characterized by a notable mountainous relief, which favours cyclogenesis and an air mass with high humidity, instability and latent energy, with the consequent development of adverse weather events such as flash floods or strong wind storms (Jansà et al., 2014). All of this makes weather forecasting, and therefore climate prediction, more complicated than usual. Beside this, the sociocultural and historical context is enormously heterogeneous, and the distribution of resources is very uneven. The North of the region presents greater well-being, economic development and governmental stability, while the South and the Middle East are characterized by rapid population growth, from about 105 million people in 1960 to more than 440 million in 2017. Climate change exacerbates all of these differences, even more so if one considers that a large number of the population currently lives in coastal areas, and it is expected that by 2050 this will reach $70 \%$ of the total.

Floods in the Mediterranean region are usually sudden, known in English as flash floods (Gaume et al., 2016). The coastal and pre-littoral mountain ranges (Fig. 1) favour not only torrential rain concentrated in small basins, but also heavy rain. Although there is no single definition, a flash flood is one that occurs in a small catchment area (generally less than $1000 \mathrm{~km}^{2}$ ) within 6 hours or less of the causative event (heavy rain, dam breach, levee failure, rapid thaw, or glacier floods) and often within 2 hours of the onset of high intensity rainfall (see www.nws.noaa.gov). Flash floods are generally caused by heavy rains that can be localised, affecting just one or two basins, or more widespread, producing flash floods within the framework of a major flood event.

From a climatic perspective, convective rains generally occur in summer and early autumn, because they are favoured by low-level instability and high temperatures (Llasat et al., 2016a; Papagiannaki et al., 2013). In the Mediterranean region, summer events are often local and short-lived, while in autumn the warmer sea surface temperature, as well as the large number of cyclones and organized weather disturbances, can lead to catastrophic events.

\section{Methods and materials}

This article presents the most recent findings on the evolution of floods in the Mediterranean region and the possible impact of climate change. This means that it is a review paper. To compile this 
paper, the main studies published on flood trends in the last decade have been taken into account, which have been synthesized, for the most part, in the First Report on Climate and Environmental Change of the Mediterranean (First Mediterranean Assessment Report, MAR1) carried out by the network of Mediterranean Experts on Climate and Environmental Climate Change (MedECC).Today MedECC is made up of more than 600 scientists from the fields of climatology, hydrology, biology, oceanography, social sciences, etc. From them, 85 scientists from 19 countries took part in this MAR1 report (MedECC, 2020). The impact of MAR1 was already evident in the previous report (MedECC, 2019) presented at COP-24 and at the 4th Meeting of Foreign Ministers of the Union for the Mediterranean held in Barcelona in October 2019. It also constitutes the basis of the 6th AR of IPCC Cross-Chapter Paper 4: Mediterranean Region. The present contribution includes the most important results of the MedECC (2019) report and the paper by Cramer et al. (2018).

Other recent publications focused on flood trends and flood variability in the Mediterranean region have been also considered. This focus on flood variability justifies why not all the articles on floods in the Mediterranean have been included here, since they constitute an unapproachable base. As an example, we could refer to Gaume et al. (2016) that offers a broad perspective on Mediterranean extreme floods and flash floods. But there are also papers that present flood databases, such as those by Gil-Guirado et al. (2016) and Llasat et al. (2014); other papers are mainly focused on the analysis of events such as those referring to the flash floods recorded in Genoa in 2014 (Hally et al., 2015); other works are focused on the analysis of the social impact of floods (ex. Papagiannaki et al., 2013); finally, we cannot forget those focused on the aspects of hydrometeorological modelling, either by applying hydrological models (ex. Braud et al., 2010) or mesoscale meteorological models (ex. Martín et al., 2007).

It must also be considered that most of the floods in this region are flash floods and coastal floods; riverine flooding is less frequent and ice jam flooding usually do not occur. Urban floods and surface water floods (Cortès et al., 2018) are also included here.

\section{Main factors involved in flood risk}

The United Nations Office for Disaster Risk Reduction (UNDRR) recently published a Technical Review Report on hazard definitions that support the three landmark agreements adopted by the United Nations in 2015: the Sendai Framework for Disaster Risk Reduction 2015-2030, the Sustainable Development Goals in the 2030 Agenda, and the Paris Agreement on Climate Change (UNDRR, 2020). This report assumes the definition of 'hazard' adopted by the United Nations General Assembly (UNGA) in February 2017; namely, "a process, phenomenon or human activity that may cause loss of life, injury or other health impacts, property damage, social and economic disruption or environmental degradation". Consequently, to consider a phenomenon as a hazard, it needs to fulfil each of three criteria: has the potential to impact a community; has measurable spatial and temporal components; proactive and reactive measures are available. This definition excludes complex human activities and processes where it is difficult to identify a single or limited set of hazards, compound and cascading hazards, and underlying disaster risk drivers such as climate change. On the other hand, floods are considered a hydrometeorological hazard. The UNISDR (2009) defined a hydrometeorological hazard as the process or phenomenon of atmospheric, hydrological or oceanographic nature that may cause loss of life, injury or other health impacts, property damage, loss of livelihoods and services, social and economic disruption, or environmental damage. Figure 2 shows the different categories of hazards, while Figure 3 shows the different types of hydrometeorological hazards. A total of 318 hazards were reported by countries in 2019 as part of the Sendai Framework Monitor, of which the majority corresponded to hydrometeorological hazards-a total of 120 . However, a large number of them were the same, with different denominations according the country. Figure 3 shows the most important ones. They have been classified according to the drivers, those that have an exclusively atmospheric origin (meteorological or climatological, like heavy rain), a mixed origin between atmospheric factors and 
other hydrological or geological factors, and a non-atmospheric origin. Floods are a mixed hydrometeorological hazard and is possible to distinguish between four types. The UNISDR (2009) introduced the concept of socio-natural hazards as the phenomenon increased in occurrence due to land and environmental degradation and included floods among them.

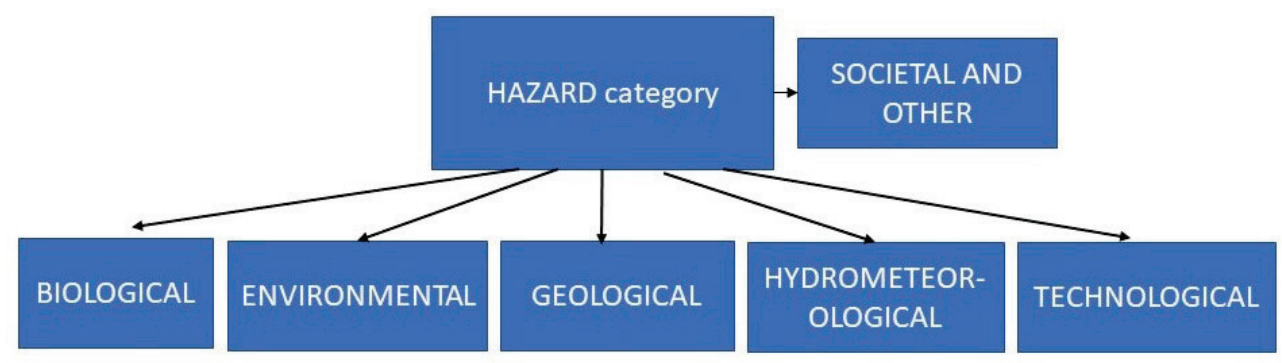

Figure 2. Types of hazards following UNDRR (2020).

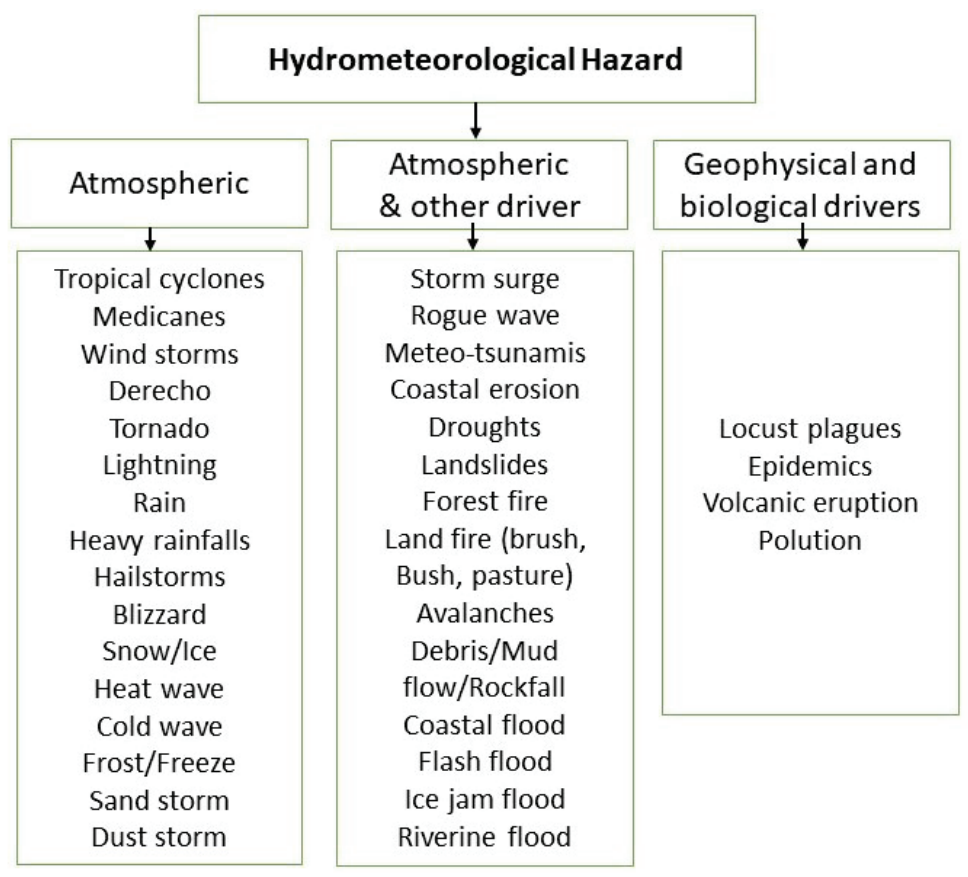

Figure 3. Main hydrometeorological hazards.

In 2009, the UNISDR (United Nations International Strategy for Disaster Reduction) defined risk as the combination of the probability of an event and its negative consequences (UNISDR, 2009). This definition was transferred to Eq. 1, where hazard $(\mathrm{H})$ would include the probability of an event of determined characteristics (i.e. rainfall intensity) and vulnerability (V) would refer to potential negative consequences and usually also included exposure and risk management (Llasat et al., 2009) (Eq.1). The UNISDR (2009) defined vulnerability as the characteristics and circumstances of a community, system or asset that make it susceptible to the damaging effects of a hazard, and included in it factors such as the poor design and construction of buildings, inadequate protection of assets, lack of public information and awareness, limited official recognition of risks and preparedness measures, and disregard for wise environmental management. This kind of definition has been widely used to build risk maps as the combination of hazard maps and vulnerability factors. It has the advantage that allows the use of a colour code based on a matrix that combines hazard and vulnerability. In this case, flood hazard maps would show the potential flooded area for a given return period, while the vulnerability factors would include 
the type of building in the flooded area and its purpose of use (school, hospital, etc.). Floods are a natural hazard but not a natural disaster, because disasters are not "natural" due to their relationship with nonnatural aspects like vulnerability.

$$
\mathrm{R}=\mathrm{H} \times \mathrm{V}
$$

However, different scientific communities distinguish exposure as a differentiating factor. In the GAR report (2019), the UN defined risk as the combination of hazard, exposure and vulnerability (Eq. 2).

$$
\mathrm{R}=\mathrm{H} \times \mathrm{V} \times \mathrm{E}
$$

The recent report by the UNDRR (2020) modifies the preceding definitions and gives special importance to the capacity of the community to cope with risk and recover, which is nowadays known as resilience. The UNDRR (2020) state that Hazards together with vulnerability, exposure and capacity, all contribute to disaster risk. Following this statement, the risk equation would be Eq. 3

$$
\mathrm{R}=\mathrm{H} \times \mathrm{V} \times \mathrm{E} \times \mathrm{C}
$$

Considering Eq. 3, flood risk can change as a consequence of changes in hazard, vulnerability, exposure and coping capacity. In relation to floods, climate change can have an impact on the hazard, and environmental change can have an impact in vulnerability but also in flood hazard. National and regional plans devoted to adaptation to climate change usually refer to risk mitigation in order to diminish risk exposure and improve capacity. Nowadays the three equations coexist, and the most useful one to avoid confusion is the use of indicators for different variables. For instance, Aroca-Jiménez et al. (2018) propose an Integrated Economic Vulnerability Index (IEVI) for urban areas, which essentially considers three components: 1) Exposure (potential damage caused in areas prone to flooding, and potential damage at an individual level); 2) Sensitivity (level of wealth and economic capacity of urban areas to cope with the consequences of floods); 3) Resilience (ability of citizens to cope with the consequences of flash floods).

Another type of indicator is the impact on human lives. Petrucci et al. (2019) have published the EUFF (European Flood Fatalities) database, which contains all the people who have died as a result of the floods in some regions of Europe, most of them in the Mediterranean (Czech Republic, Israel, Italy, Turkey, Greece, Portugal, southern France, Catalonia and the Balearic Islands) for the 1980-2018 period. This work identifies 812 fatal floods with 2466 deaths, so, on average, each event killed 3 people. The probability of dying during a flood depends essentially on the physical parameters that characterize the hazard (i.e. the speed of the water, the height of the water level and the turbidity of the water), vulnerability (i.e. the construction characteristics of the house), exposure (i.e. if the victim is in a floodprone area), and the human-flood interaction (i.e. whether the victim has responded correctly to early warnings).

The number of casualties as a consequence of floods, as well as the economic damages, provide integrated information on the flood risk disaster, and it is difficult to distinguish between the weight of each factor in Eq.3. On the other hand, when floods are only estimated from a discharge threshold, we are working from a flood hazard approach. Both approaches are used interchangeably in the literature, which can create confusion. Added to this is the lack of homogeneity of the series, their short duration, and the poor spatial representation, since many floods are due to local rainfall. This leads to different authors reaching contradictory conclusions. In the following chapters it will be necessary to keep these considerations in mind. Given that what we are dealing with here is the variation of floods in a context of climate change, we will begin by presenting the most relevant conclusions about the Mediterranean region. 


\section{Main environmental and climate changes in the Mediterranean Region}

The article by Cramer et al. (2018) shows that the Mediterranean region has warmed $1.4^{\circ} \mathrm{C}$ compared to the pre-industrial period (about $0.03^{\circ} \mathrm{C} /$ year), which is $20 \%$ more than the global average (Fig. 4). The greatest increases in temperature are recorded in the summer, accompanied by a higher frequency of heat waves and tropical nights (the minimum temperature does not drop below $20^{\circ} \mathrm{C}$ ). There is a longer duration of consecutive days without rain throughout the region, in addition to an increase in droughts. The temperature of the Mediterranean Sea has increased by about $0.4^{\circ} \mathrm{C} / \mathrm{decade}$ between 1985 and 2006, increasing more in the East (about $0.5^{\circ} \mathrm{C} /$ decade) than in the West (about $0.3^{\circ} \mathrm{C} /$ decade). Recently, Pastor et al. (2020) have showed that Sea Surface Temperature (SST) of the Mediterranean has increase $1.3^{\circ} \mathrm{C}$ between 1982 and 2019. This warming is greatest in May, June and July. The oceans absorb 30\% of anthropogenic carbon dioxide, increasing its acidity and damaging marine ecosystems. A decrease in $\mathrm{pH}$ of 0.1 has been observed and it is estimated that levels will continue to decrease by 0.018 and 0.028 per decade.

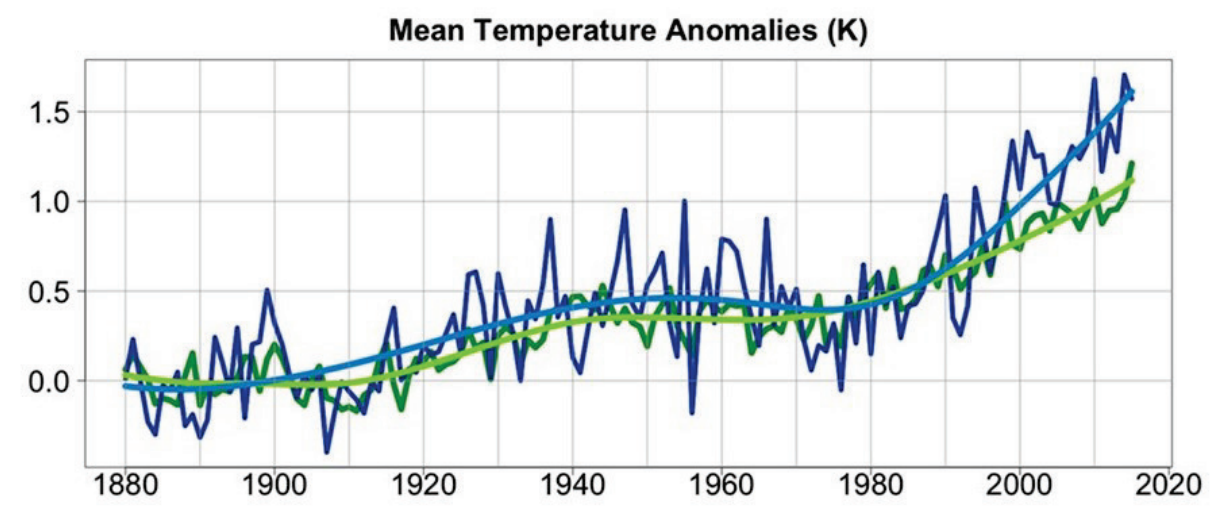

Figure 4. Increase of the annual temperature anomaly in comparison with the period 1880-1899 (green: world average; blue: Mediterranean region) (from Cramer et al., 2018).

As a result of global warming, the level of the Mediterranean Sea rose $1.1 \mathrm{~mm} /$ year between 1970 and 2006, which is being aggravated by the loss of ice from Antarctica and Greenland. Terrestrial ecosystems suffer from the loss of biodiversity both due to climate change and changes in land use, overexploitation and pollution. The abandonment of agricultural practices and livestock grazing areas, especially in the North, is one of the main causes, exacerbated by an increase in forest areas prone to fire. It should be said, however, that burned areas show a downward trend in the Mediterranean region, except for some areas in Sicily or Portugal, due to improved fire prevention and extinction. Even so, the scenarios point to an increase close to $40 \%$ with an increase of $1.5^{\circ} \mathrm{C}$, and more than $100 \%$ if the increase reaches $3^{\circ} \mathrm{C}$ (Turco et al., 2018).

Without mitigation measures, temperatures will increase by $2.2^{\circ} \mathrm{C}$ in 2040 and will exceed $3.8^{\circ} \mathrm{C}$ in some subregions by 2100 , aggravated by the urban heat island effect in cities, which increase these temperatures by around $4^{\circ} \mathrm{C}$. For many of the large cities in the MENA region (North Africa and Eastern Mediterranean) the coolest summer will be warmer than the coldest summer month at the present. For each degree that the temperature increases, precipitation will decrease by around $4 \%$, especially in the South. For more than $2^{\circ} \mathrm{C}$, in some regions it may decrease by $30 \%$ (i.e. Turkey), and the frost season may even disappear (i.e. in the Balkans).

The models show an increase in heavy rains in the North, which is precisely the region most affected by floods, while in the South heavy rains are expected to decrease. On the other hand, extreme droughts will be more frequent than at present. The increase in the duration of these dry spells is expected to be $7 \%$ for an increase of $1.5^{\circ} \mathrm{C}$. At $2^{\circ} \mathrm{C}$ it is calculated that the fresh water available for consumption 
may decrease by between $2 \%$ and $15 \%$, which, together with an increase in demand due to population growth (between $22 \%$ and $74 \%$ ), and a decrease in underground resources, both in terms of quality and quantity, may result in some 250 million people being water poor over the next 20 years (less than $1000 \mathrm{~m}^{3} /$ year), with the greatest shortage in the East and South. In addition, an increase of between $4 \%$ and $18 \%$ in terms of water needs for irrigation is expected (this constitutes between $50 \%$ and $90 \%$ of the total demand).

Depending on emission scenarios, it is calculated that the temperature of the Mediterranean Sea may increase by between $1.8^{\circ} \mathrm{C}$ and $3.5^{\circ} \mathrm{C}$ in 2100 . Acidification and the increase in sea temperature would lead to the loss of $41 \%$ of marine predators (including mammals), and an increase in the intensity and extent of jellyfish colonies, as well as the invasion of more than 700 non-native species (plants and animals) including predators such as lionfish, most from the Red Sea, which would cause greater losses in the native habitat. It should be added that overfishing has led to the loss of $34 \%$ of fish species. By 2100 the sea level could have risen between 52 and $190 \mathrm{~cm}$. The impacts of these changes are very serious, since a third of the population lives in coastal regions, with more than 37 million people living in coastal areas in North Africa. By 2050, it is expected that half of the 20 cities in the world that will most suffer from rising sea levels are in the Mediterranean. These impacts include, among others, coastal erosion and damage to infrastructure on the coast, increased saline intrusion and coastal flooding, and the loss of beaches, agricultural areas and marshes.

\section{Trends}

The high increase in temperature and sea levels presented in the previous section could have several effects on floods:

- An increase in evapotranspiration and therefore in the mass of precipitable water in the atmosphere.

- An increase in atmospheric instability.

- An advance in the thaw season that would cause an increase in water flow at unusual times.

- A decrease in discharge due to evaporative loss.

- A decrease in soil humidity.

However, one of the key messages of MedECC (2019) is that past trends for precipitation are not so robust in quantity and magnitude, since internal climate variability limits our capability to detect long-term trends. In the same way, there is not a common sign pointing to an increase in floods. The special report on extremes by the IPCC (2012) stated that it is likely there has been a worldwide increase in extreme high-water events during the late 20th century, with a likely anthropogenic influence on it. The AR5 of IPCC (2014) and the IPCC SR1.5 (IPCC, 2018) also conclude that there is "limited to medium" evidence available to assess climate-induced changes in the magnitude and frequency of floods on a regional scale, with evidence of "low agreement" and "low confidence" on a global scale to detect these, but, despite this absence of changes in flood occurrence or magnitude, there is an increase in flood losses due to an increase in exposure and vulnerability to floods ("medium confidence").

Consequently, when discussing flood trends and trying to associate the cause with the effect, a very cautious position must be taken (Merz et al., 2012; Hall et al., 2014). The main sources of uncertainty or even, in some cases, of confusion, are the following:

- The strong variability of rainfall in the Mediterranean region (affects the hazard).

- Ignorance of some of the factors responsible for heavy rains (hazard). 
- The influence of environmental changes in the catchments (hazard).

- Changes in the basin either in terms of land use or hydraulic infrastructures (Merz et al., 2012; Hall et al., 2014) (can affect the hazard and vulnerability).

- Changes in exposure, response capacity, early warning, etc. (Kreibich et al., 2017).

- The semantic confusion that sometimes exists between heavy rains and floods (hazard).

- The concept of flooding. From a "top-down" perspective, an extreme value of flow is usually understood as such, regardless of whether there are impacts or not. In turn, the concept of extreme can be quantified in numerous ways (return periods, exceeding thresholds, etc.) (i.e. Blösch et al., 2019). If the perspective is "bottom-up", it is usually based on the information about the damage produced, without taking into account the frequency of the event. In this case, the selection criteria can be very different, completely affecting the sample analysed (Llasat et al., 2013b) (affects flood risk estimation).

- The length, homogeneity and period comprised by the series analysed (Llasat et al., 2013b) (affects flood risk trend estimation).

- The reliability of the measurements and observations, as well as the quality and continuity of the information (Llasat et al., 2013b) (affects the flood risk trend estimation).

- The event quantification methodology that can refer to the basin or region as a whole, to all the points for which the impact is recorded, or the total hydrometeorological episode (see, for example, the difference between the criteria of Barriendos et al., 2003, where they count the number of floods from the affected localities, and Llasat et al., 2013b, in which they count the episodes)

In the synthesis that is presented below, there does not have to be an agreement between authors, or even for the same author in different contexts, so whenever it was possible to find out, what is understood by flood, the period to which it refers, etc., is given in brackets.

\subsection{Secular changes}

A study recently published in Nature (Blösch et al., 2020) shows the compilation and analysis of all historical flood series in Europe from 1500 to 2016, taking data from archives, the press, etc. In order to homogenize the information, all the texts were placed in their respective historical contexts with meticulous attention to detail in order to make them comparable. This allowed for a regionalization to be created, identifying nine flood-rich periods. Notable periods include 1560-1580 (western and central Europe), 1760-1800 (most of Europe), 1840-1870 (western and southern Europe), and 1990-2016 (western and central Europe). Comparisons of air temperature reconstructions show that these historical flood periods were substantially colder than the intermediate phases, which appears to contradict the observation that, in some areas, such as north-western Europe, the recent warmer weather is linked with major flooding. The article therefore argues that the underlying mechanisms may have changed and that the hydrological conditions of the present are very different from those of the past. This is compounded by a change in seasonal distribution: previously, $41 \%$ of floods in Central Europe occurred in the summer, compared to $55 \%$ today. These changes could be related to changes in precipitation, evaporation and thaw, constituting an important indicator to distinguish the role of climate change from other control factors such as deforestation and river management. 
The secular variation of floods in the northwest Mediterranean region has already been analysed in the SPHERE project (Benito et al., 2004). On the one hand, a positive trend was obtained from the episodes considered as extraordinary (floods that caused significant damage, but not total destruction of bridges, buildings or mills) from the end of the 19th century, which was mostly linked to changes in land use (Fig. 5). On the other hand, anomalous periods of catastrophic floods (with total destruction of infrastructure) were identified, mainly concentrated around the Little Ice Age (Barriendos et al., 2003; Llasat et al., 2005), which would be in line with the observations of Blösch et al. (2020). The detailed analysis of the so-called Maldá Oscillation, characterized by the high number of floods between 1760 and 1800 (Fig. 6), showed an anomaly in the NAO index (Barriendos and Llasat, 2003) linked to atmospheric circulation in the north Atlantic. Barrera-Escoda and Llasat (2015) extended the series to 1301-2012 and analysed not only the relationship with the NAO but also with solar activity, finding a significant negative correlation ( -0.42 for the autumn season). From a physical point of view, the most recent explanations focus on the influence of the heating and cooling of regions of the stratosphere with the consequent impact on the tropospheric circulation, giving weight to possible teleconnections, such as the NAO (Ermolli et al., 2013). In turn, the synoptic-scale circulation will give some types of weather that may favour the development of intense rains, which are the main cause of floods in the Mediterranean, such as the presence of synoptic or mesoscale lows (Gilabert and Llasat, 2017, Jansà et al., 2014). These results are consistent with the studies that are currently being carried out to find the sources of water vapour that feed the intense rains in the Mediterranean and that demonstrate the notable role of sources of Atlantic origin, against the existing perception that most came from the Mediterranean (Insua-Costa et al., 2019). In this context, the latest flood episodes that have affected the Spanish Mediterranean coast would be a call for reflection, given the influence that the Greenland thaw has on large-scale climate variability over the Mediterranean basin, partially associated with circulation patterns such as the Arctic Oscillation (AO) and the North Atlantic Oscillation (NAO), which control part of the moisture fluxes over the western and eastern Mediterranean basins (Tramblay and Hertig, 2018).

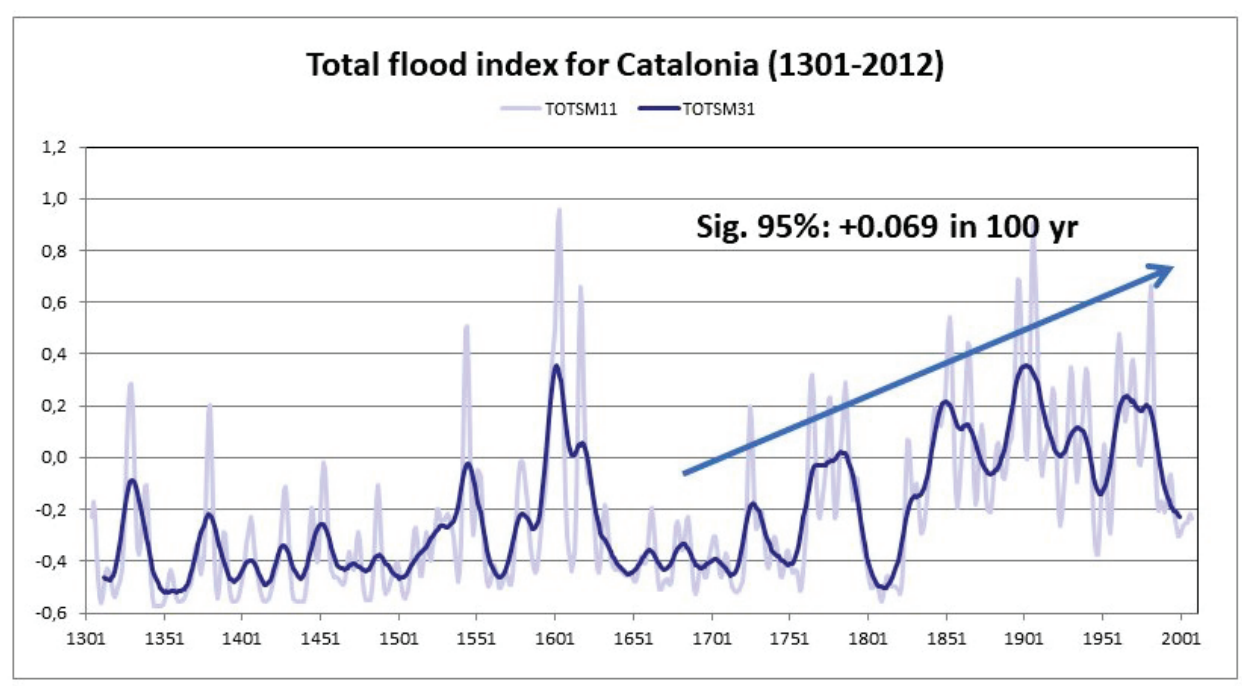

Figure 5. Floods evolution in Catalonia since the 14th century. The positive trend is due to the extraordinary floods (from Barrera-Escoda and Llasat, 2015). 


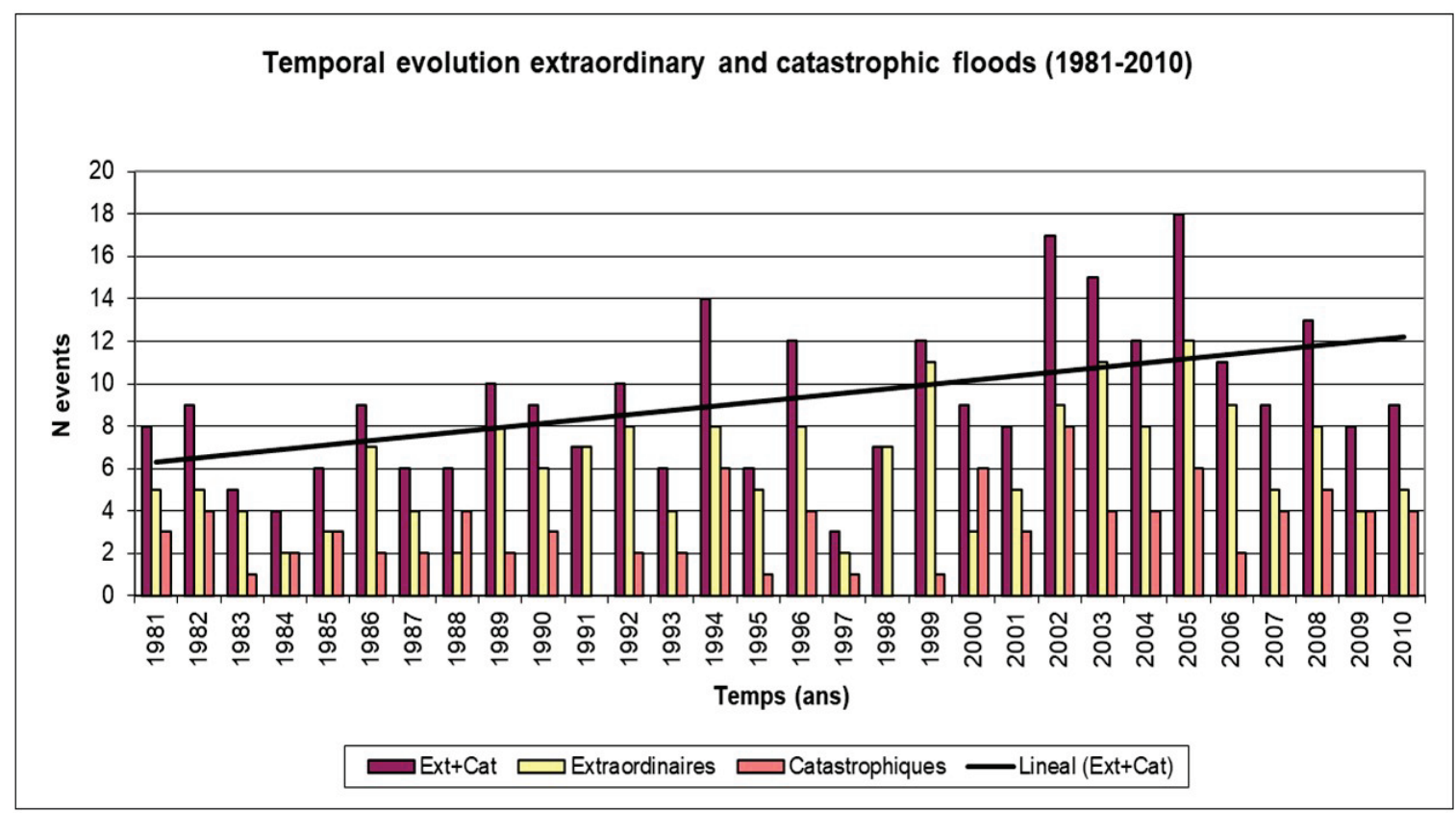

Figure 6. Temporal evolution of total floods recorded in Catalonia and the Balearic Islands (Spain), southern France, and Calabria (Italy). The category in basis to the damages produced is distinguished (catastrophic have worse impacts than extraordinary), (from Llasat et al., 2013a).

\subsection{Recent changes}

When we expand the temporal resolution and bring the scale closer to current times, the influence of other non-climatic factors takes on greater prominence. An example of a detailed work that analyses changes in precipitation, river discharge and uses of soil is the one by Tramblay et al. (2019). They analysed 171 daily discharge data series with a median record length of 45 years (minimum of 20 years of daily discharge data), in southern France, besides other hydrometeorological outputs obtained from the SAFRAN reanalysis (Quintana-Seguí et al., 2008) and the ISBA land surface model (Habets et al. 2008), as well as the evolution of land cover using the CORINE database between 1990 and 2018. Floods are estimated using two different percentiles: moderate floods (above the 95th percentile of daily runoff in all stations) and more severe floods (above the 99th percentile). The trends in floods between 1958 and 2018 are detected by a corrected Mann-Kendall test (to avoid the effect of serial correlation, Sen, 1968). To estimate the magnitude of the temporal trend, the quantile regression method was applied (Koenker and Basset, 1978). They found that the intensity of the most extreme floods shows significant upward trends in only a few basins, while most trends are towards fewer annual floods, which they associate to a reduction in soil moisture as a consequence of increased temperatures and a decrease in evapotranspiration and precipitation. In general, the larger catchments show significant downward trends in flood occurrence, and forest areas show more negative trends than agricultural catchments. An increase of up to $20 \%$ and $36 \%$ in urban areas and discontinuous urban fabric, respectively, can have a strong impact on runoff generation due to an increase in impervious surfaces. In urban catchments with a lower increase in urbanization, trends are negative, while for the rest of them no trends were found. The work of Tramblay et al. (2019) shows that with the same large-scale climatic drivers (in terms of temperature, evapotranspiration and precipitation), the flood trends in the basins can differ, even for neighbouring basins, as a consequence of other factors like topography, soil and land cover combinations. 
A similar study was carried out for the Barcelona Metropolitan Area (Llasat et al., 2016b). As all of the floods in the area (mainly surface water floods and urban floods) were due to heavy rainfalls, the contribution explored the evolution of land use, population, precipitation and coping capacity. The results confirmed the strong role played by the increase in urban surfaces and impermeable soil (like the new airport) which gave rise to an increase in extraordinary floods, despite the fact that maximum precipitation showed no increase, with the exception of Barcelona. This city was recognized by the UNDRR as a resilient city to floods, due to the implementation of early warning systems and rainwater tanks (Nakamura and Llasat, 2017)

While most studies agree that flood damage is increasing (Barredo et al., 2012, CREDUNISDR, 2015), observations point to the opposite in some regions. In Spain and southern France, generally decreasing trends have been found in maximum annual flows (Mediero et al., 2014; Renard et al., 2008). The attribution of these negative trends could be related to the increase in forested areas in the upper part of the river basins because of a decrease in cultivated areas (Hall et al., 2014). For the Po river (Italy), a clear trend is not observed in terms of annual maximum floods (Montanari, 2012). In contrast, Greece has seen an increase in the frequency of floods in recent decades (Diakakis, 2014). For the Mediterranean basins, Mangini et al. (2018) shows a trend towards an increase in the magnitude of floods, but a decrease in frequency.

The analysis by Blöschl et al. (2019) from the most complete database of floods in Europe for the 1960-2010 period (understood as extremes of flow) shows a decreasing trend for the Mediterranean region in medium and large basins, mainly due to a decrease in precipitation and increased evaporation. In Spain in particular, the change in the average annual discharge of floods per decade would be between -5 and $-12 \%$. This divergence from observed trends in maximum flood discharge and damage may be associated with other parameters, such as exposure and vulnerability. In fact, Barredo et al. (2012) show that the increased economic impact of floods in Spain may be due, in part, to an increase in insured property and the cost of living. In the comparative analysis of pairs of events that occurred in the same region at two different times (for example, the episodes of 10 June, 2000, and 25 September, 1962, in Catalonia) and for different parts of the world, Kreibich et al. (2017) conclude that in general the impact of floods has decreased in the most economically developed countries, mainly due to changes in habits and behaviours, both due to general improvements in the cultural level of the population and improvements in preventive measures, the early warning system and emergency management, which is not an obstacle to an increase in the value of exposed assets.

In the case of Mediterranean countries, there is another important factor-most floods occur in ungauged torrential basins, mainly affecting the coast, where the population and urban settlements are increasing rapidly in flood-prone areas (Gaume et al., 2016). Thus, a detailed and systematic analysis shows an increase in floods in regions of Italy, France and Spain for the 1981-2010 period (Llasat et al., 2013a) (Fig. 6). This increase is not found when we refer to catastrophic floods (Fig. 7), as we have also observed in longer historical series (Barrera-Escoda and Llasat, 2015; Barriendos et al., 2019), that are usually consequence of more organised convective systems in well-defined meteorological patterns. This positive and significant trend of 2,5 floods/decade would be mainly due to extraordinary floods, usually associated to local heavy rainfall events in non-gauged catchments, usually surrounded by very populated villages, as a consequence of an increase in vulnerability and exposure, despite improved coping capacities 


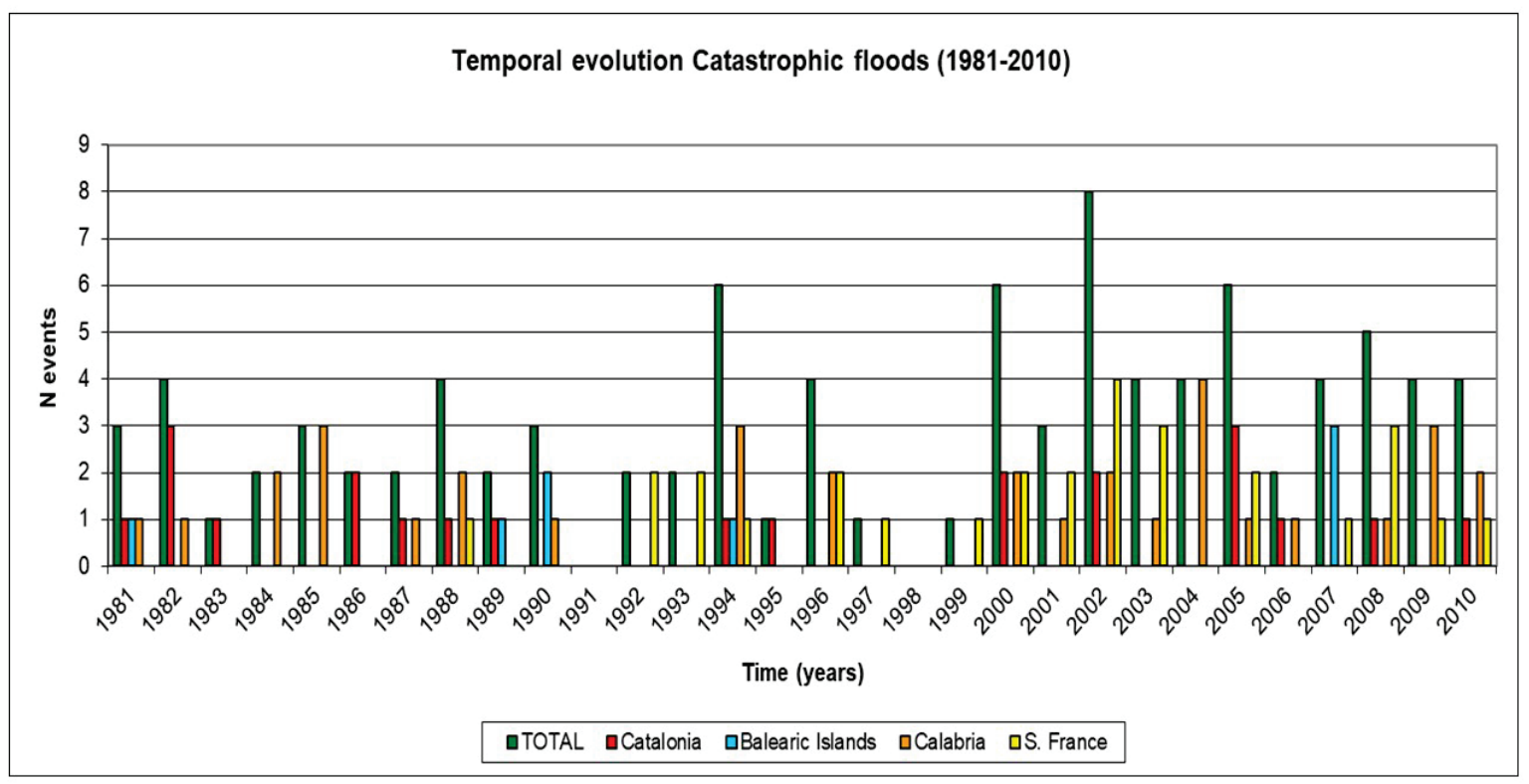

Figure 7. Temporal evolution of catastrophic floods recorded in Catalonia and the Balearic Islands (Spain), southern France, and Calabria (Italy), (from Llasat et al., 2013a).

Regarding precipitation, no significant trend is observed in the upper extremes on a daily scale. However, Llasat et al. (2016a) found a small trend in the period 1996-2011, in north-east Spain, in the increase in convective precipitation concentrated in fewer events, which would be consistent with the increase in local flash floods. The analysis of 5-min precipitation series for a longer period (1989-2015) in the eastern and north-eastern part of the Iberian Peninsula corroborates this increase in convective precipitation, mainly in the coastal area and concludes, with medium confidence, that an increase in total and convective precipitation has been found in autumn, while a decrease in total precipitation but an increase in the convective contribution has been found in summer. Considering that convective precipitation can contribute with more than $30 \%$ to total precipitation and, in some months, with more than $90 \%$, this trend is relevant (Llasat et al., 2021). This strong role of convective precipitation that gives place to heavy rainfalls and flash floods can be explained by the orography surrounding the Mediterranean Sea, the high frequency of surface lows (Romero et al., 1999; Jansà et al., 2014) and the strong potential instability in low levels favored by a warm sea. Pastor et al. (2020) have found a continuous warming trend of $0,035^{\circ} \mathrm{C} / \mathrm{y}$ of SST for the entire Mediterranean, that means an accumulated change of $1,3^{\circ} \mathrm{C}$ between 1982 and 2019, while Cramer et al. (2018) have observed an increase of $1^{\circ} \mathrm{C}$ for the entire Mediterranean Region and the same period. This differential trend between SST and air temperature near surface would be indicating a worsening of the thermodynamic conditions favorable to convection.

\subsection{Projections}

The MedECC (2020) report concludes that due to alterations in general climate circulation, most climate simulations suggest reduced future precipitation associated with increased evaporation, leading to a decline in runoff. Despite the general drying which is expected to be associated with more prolonged and severe droughts, extreme rainfall will likely increase in the North of the basin but probably decrease in the South (Tramblay and Somot, 2018; Colmet-Daage et al., 2018). 
Most of the studies refer to precipitation projections, and there are hardly any studies that obtain flow projections. For the Mediterranean, the most famous study is by Alfieri et al. (2015). They apply the group of downscaled climate projections EURO-CORDEX (Coordinated Downscaling Experiment over Europe), forced by the RCP8.5 (Representative Concentration Pathway, $8.5 \mathrm{Wm}^{2}$ ), to drive the distributed hydrological model Lisflood (Burek et al., 2013) over extreme streamflow events $\left(5 \mathrm{~km}^{2} \times 5\right.$ $\mathrm{km}^{2}$, daily step). Lisflood is the operational model adopted by the European Flood Awareness System (Thielen et al., 2009). The results are expressed as relative changes from baseline scenarios (1970-2005). Data are aggregated over both time (2006-2035, 2036-2065, 2066-2095, and referred to as "2020", "2050", and "2080", respectively) and space (precipitation variables are aggregated over 22 European river basins with an upstream area at the outlet larger than $50,000 \mathrm{~km}^{2}$ ). The Mann-Kendall test (Kendall, 1975; Mann, 1945) is performed to evaluate the statistical significance of the trends. Two selected discharge variables are extracted directly from the Lisflood model output (average streamflow Q, mean annual daily peak flow QMAX), while extreme values are obtained using the peak over threshold (POT) approach after fitting a Gumbel extreme value distribution using the L-moments approach (Hosking, 1990); they are the discharge peaks exceeding the return period of 2 years (performed on each grid point on the European river network), 100 years and 500 years (Q100 and Q500, aggregated at a river basin and country level). Following Alfieri et al. (2015), the climate projections agree on a 30\% reduction in annual precipitation in southern European countries, particularly in the Iberian Peninsula, Greece and southern Italy. The average streamflow (Q) follows the same behaviour, with negative changes in southern Europe (i.e. lower than $40 \%$ in southern Spain) as a result of a reduction in annual precipitation and increased evapotranspiration. Although some rivers in southern Europe QMAX, Q100 and Q500 show significant positive trends by 2080 (i.e. the Ebro, Duero, Garonne, Po and Rhone rivers), in general they show a discontinuous pattern and some regions do not agree with the ensemble models. On the other hand, a reduction of peak discharges in the Guadalquivir basin (less precipitation and more evapotranspiration) is clear, and the events with a return period of 2 years will be less frequent in the future in the Guadiana and Guadalquivir rivers.

Cortès et al. (2019) show changes in the probability of flood damage in eastern Spain (specifically in the autonomous communities of Catalonia and Valencia) as a result of global warming of $1.5^{\circ}, 2^{\circ}$ and $3^{\circ} \mathrm{C}$ above pre-industrial levels and bearing in mind different population scenarios. The model uses a set of seven regional climate model simulations from the EURO-CORDEX project (Jacob et al., 2014), and considers 5 different socioeconomic scenarios that include projections of population, urbanization and Gross Domestic Product on a global and national scale (O 'Neill et al., 2014). The results point to an increase in the probability of an event with significant economic damage occurring, with greater increases with increased warming and when both climate change and population change are included. The study does not deal with flood projections but with precipitation on a daily scale, given the remarkable correlation observed between rain and flood impact, taking the $40 \mathrm{~mm}$ threshold as the indicative of the possibility of sudden flooding in small basins when such an amount is collected in a very short period of time.

\section{Conclusions}

Throughout this paper we have analysed floods in the Mediterranean in a context of climate and environmental change. In summary, the most notable conclusions are the following:

1. There is insufficient evidence that river floods are increasing in the Mediterranean.

2. There is a natural variability already detected in secular series that is still not completely explained.

3. Flash floods in small non-gauged basins are increasing due to increased vulnerability and exposure, but it seems that the hazard is also increasing in some zones due to more intense and concentrated rains in very short periods of time, together with the degradation of the basins. 
4. A change in the hydrometeorological pattern is detected in the floods in Europe, which may be associated with both thermodynamic conditions that favour convection, and dynamics on a global scale.

5. Future projections point to an increase in heavy rains, especially in Mediterranean Europe, and an increase in the South of the Mediterranean.

6. Future projections show a decrease in flood hazards in some Mediterranean rivers (mainly in southern Spain) and an increase in others (i.e. the Ebro river) at the end of the $21^{\text {st }}$ century.

7. Taking into account future rainfall and socioeconomic scenarios, the probability of high-impact flood events will increase as the temperature rises.

8. Due to the high spatial variability and the high degree of complexity in the relationships between the factors involved in flood risk, the use of integrated indices is proposed.

9. It is necessary to include variables that consider changes in climatic and socioeconomic conditions in flood damage analysis.

10. Flood management must be approached from an integrated and holistic point of view that includes improved risk awareness among the population and their participation in the formulation of mitigation strategies.

These strategies should bear in mind the Third World Conference for Disaster Risk Reduction of the United Nations and the agreements in the Sendai Framework (18 March 2015). These agreements can be summarized, in the floods case, in: reducing the global average mortality rate, the global average number of affected people, the direct economic loss and the damage to critical infrastructure and the disruption of basic services; and increase the number of countries with national and local flood risk reduction strategies, the international cooperation, the availability and the access to multi-hazard early warning, information and disaster risk assessment systems. These goals should be achieved by following the four priorities for action relatives to flood disaster risk: understanding, strengthening governance, investing to improve resilience, and improving disaster preparedness in terms of recovery, rehabilitation and reconstruction.

The Sendai Framework joined the 2007 EU Floods Directive (Directive 2007/60 / EC) offer a good flood risk management philosophy (Nakamura and Llasat, 2017). In the case of the Mediterranean, the projected increase in population on the coast, a flood-prone area, does not benefit compliance with the Sendai agreements. There is also a second and important problem centred on the differences between the European part, which is much more resilient, and the MENA region (North Africa and Mediterranean Asian countries), except for Israel, show fewer copying capacities. Although the climatic scenarios point to a greater increase in intense rains in the northern part, with major copying capacity, we cannot forget that the rise in sea level will also increase sea floods, and in this case, the African region can be very affected due to the proximity of agricultural areas to the sea (MedECC, 2020). The EU Floods Directive suggests the possibility of being transposed also to the other Mediterranean regions, taking advantage of the existence of the Union for Mediterranean created during the Barcelona Conference of 1995. Following the proposals of the Sendai Framework regarding international collaboration, the transfer of knowledge between experts could be improved and early warning systems could be shared. But this is only a reflection, a starting point for future multidisciplinary work and the necessary collaboration between scholars and policymakers. 


\section{Acknowledgements}

This paper has received support from the Spanish project M-CostAdapt (CTM2017-83655-C2R) of the FEDER/Ministry of Science, Innovation and Universities-AEI, and the project EFA210/16/PIRAGUA, INTERREG POCTEFA 2014-2020. It was conducted under the framework of the IAHS Panta Rhei working group 'Changes in Flood Risk'.

\section{References}

Alfieri, L., Burek, P., Feyen, L., Forzieri, G. 2015. Global warming increases the frequency of river floods in Europe. Hydrol. Earth Syst. Sci. 19, 2247-2260. https://doi.org/10.5194/hess-19-2247-2015

Aroca-Jiménez, A., Bodoque, J.M., García, J.A., Díez-Herrero, A. 2018. A quantitative methodology for the assessment of the regional economic vulnerability to flash floods. Journal of Hydrology 565, 386-399. https://doi.org/10.1016/j.jhydrol.2018.08.029

Barredo, J.I., Saurí, D., Llasat, M.C. 2012. Assessing trends in insured losses from floods in Spain 1971-2008. Nat. Hazards Earth Syst. Sci. 12, 1723-1729. https://doi.org/10.5194/nhess-12-1723-2012

Barrera-Escoda, A., Llasat, M.C., 2015. Evolving flood patterns in a Mediterranean region (1301-2012) and climatic factors - the case of Catalonia. Hydrol. Earth Syst. Sci. 19, 465-483. https://doi.org/10.5194/hess$19-465-2015$

Barriendos, M., Coeur, D., Lang, M., Llasat, M.C., Naulet, R., Lemaitre, F., Barrera, A., 2003. Stationarity analysis of historical flood series in France and Spain (14th-20th centuries). Natural Hazards and Earth System Sciences 3, 583-592.

Barriendos, M., Llasat, M.C. 2003. The case of the 'Maldá'Anomaly in the Western Mediterranean basin (AD 1760-1800): An example of a strong climatic variability. Clim. Change 61, 191-216. https://doi.org/10.1023/A:1026327613698

Barriendos, M., Gil-Guirado, S., Pino, D., Tuset, J., Pérez-Morales, A., Alberola, A., Costa, J., Balasch, J.C., Castelltorth, X., Mazón, J., Ruiz-Bellet, J. L. 2019. Climatic and social factors behind the Spanish Mediterranean flood event chronologies from documentary sources (14th-20th centuries). Global and Planetary Change 182, 102997. https://doi.org/10.1016/j.gloplacha.2019.102997

Benito, G., Lang, M., Barriendos, M., Llasat, M.C., Francés, F., Ouarda, T., Thorndycraft, V., Enzel, Y., Bardossy, A., Coeur, D., Bobée, B. 2004. Use of Systematic, Palaeoflood and Historical Data for the Improvement of Flood Risk Estimation. Review of Scientific Methods. Natural Hazards 31, 623-643. https://doi.org/10.1023/B:NHAZ.0000024895.48463.eb

Blöschl, G., Hall, J., Viglione, A. et al. 2019. Changing climate both increases and decreases European river floods. Nature 573, 108-111. https://doi.org/10.1038/s41586-019-1495-6.

Blöschl, G., Kiss, A., Viglione, A. et al. 2020. Current flood-rich period is exceptional compared to the past 500 years in Europe. Nature. 583, 560-566. https://doi.org/10.1038/s41586-020-2478-3.

Braud, I., Roux, H., Anquetin, S., Maubourguet, M.M., Manus, C., Viallet, P., Dartus, D., 2010. The use of distributed hydrological models for the Gard 2002 flash flood event: analysis of associated hydrological processes. J. Hydrol. 394 (1-2), 162-181. https://doi.org/10.1016/j.jhydrol.2010.03.033

Burek, P., Knijff van der, J., Roo de, A. 2013. LISFLOOD, distributed water balance and flood simulation model revised user manual 2013. European Commission Joint Research Centre Institute for the Protection and the Security of the Citizen Publications Office, Luxembourg.

Camici, S., Brocca, L., Moramarco, T. 2017. Accuracy versus variability of climate projections for flood assessment in central Italy. Climatic Change 141, 273-286. https://doi.org/10.1007/s10584-016-1876-X

Colmet-Daage, A., Sanchez-Gomez, E., Ricci, S., Llovel, C., Borrell Estupina, V., Quintana-Seguí, P., Llasat, M.C., Servat, E. 2018. Evaluation of uncertainties in mean and extreme precipitation under climate changes for northwestern Mediterranean watersheds from high-resolution Med and Euro-CORDEX ensembles. Hydrol. Earth Syst. Sci. 22, 673-687. https://doi.org/10.5194/hess-22-673-2018 
Cortès, M., Turco, M., Llasat-Botija, M., Llasat, M.C. 2018. The relationship between precipitation and insurance data for floods in a Mediterranean region (Northeast Spain). NHESS. Nat. Hazards Earth Syst. Sci. 18, 857-868. https://doi.org/10.5194/nhess-18-857-2018.

Cortès, M., Turco, M., Ward, Ph., Sánchez-Espigares, J., Alfieri, L., Llasat, M.C. 2019. Changes in flood damage with global warming in the east coast of Spain. Nat. Hazards Earth Syst. Sci. 19, 2855-2877. https://doi.org/10.5194/nhess-2019-253

Cramer, W., Guiot, J., Fader, M., Garrabou, J., Gattuso, J.P., Iglesias, A., Lange, M.A., Lionello, P., Llasat, M.C., Paz, S., Peñuelas, J., Snoussi, M., Toreti, A., Tsimplis, M.N., Xoplaki, E. 2018. Climate change and interconnected risks to sustainable development in the Mediterranean. Nature Climate Change 8, 972980. https://doi.org/10.1038/s41558-018-0299-2

CRED-UNISDR. 2015. The Human Cost of Weather-Related Disasters 1995-2015. https://www.unisdr.org/files/46796_cop21weatherdisastersreport2015.pdf

Diakakis, M. 2014. An inventory of flood events in Athens, Greece, during the last 130 years, seasonality and spatial distribution. Journal of Flood Risk Management 7 (4), 332-342. https://doi.org/10.1111/jfr3.12053

Ermolli, I., Matthes, K., Dudok de Wit, T., Krivova, N. A., Tourpali, K., Weber, M., Unruh, Y. C., Gray, L., Langematz, U., Pilewskie, P., Rozanov, E., Schmutz, W., Shapiro, A., Solanki, S. K., Woods, T. N. 2013. Recent variability of the solar spectral irradiance and its impact on climate modelling, Atmos. Chem. Phys., 13, 3945-3977. https://doi.org/10.5194/acp-13-3945-2013

Gaume, E., Borga, M., Llasat, M.C., Maouche, S., Lang, M., Diakakis, M. 2016. Mediterranean extreme floods and flash floods (Sub-chapter 1.3.4). In: IRD and Allenvi (Eds.). The Mediterranean Region under Climate Change. A Scientific Update, IRD Editions, pp. 133-144, Marseille.

Gilabert, J., Llasat, M.C. 2017. Circulation weather types associated with extreme flood events in Northwestern Mediterranean. International Journal of Climatology 38 (4), 1864-1876. https://doi.org/10.1002/joc.5301

Gil-Guirado, S., Pérez-Morales, A., López-Martinez, F. 2019. SMC-Flood database: a high-resolution press database on flood cases for the Spanish Mediterranean coast (1960-2015). Nat. Hazards Earth Syst. Sci 19, 1955-1971. https://doi.org/10.5194/nhess-19-1955-2019

Habets, F., Boone, A., Champeaux, J.L., Etchevers, P., Franchisteguy, L., Leblois, E., Ledoux, E., Le Moigne, P., Martin, E., Morel, S., Noilhan, J., Quintana-Segui, P., Rousset-Regimbeau, F., Viennot, P. 2008. The SAFRAN-ISBA-MODCOU hydrometeorological model applied over France. J. Geophys. Res. 113, D06113, https://doi.org/10.1029/2007JD008548

Hall, J., Arheimer, B., Borga, M., Brázdil, R., Claps, P., Kiss, A., Kjeldsen, T.R., Kriaučiūnienė, J., Kundzewicz, Z.W., Lang, M., Llasat, M.C., Macdonald, N., McIntyre, N., Mediero, L., Merz, B., Merz, R., Molnar, P., Montanari, A., Neuhold, C., Parajka1, J., Perdigão, R.A.P, Plavcová1,L., Rogger. M., Salinas, J.L., Sauquet, E., Schär, C., Szolgay, J., Viglione, A., Blöschl, G. 2014. Understanding Flood Regime Changes in Europe: A state of the art assessment. Hydrol. Earth Syst. Sci. 18, 2735-2772. https://doi.org/10.5194/hess-18-2735-2014

Hally, A., Caumont, O., Garrote, L., Richard, E., Weerts, A., Delogu, F., Fiori, E., Rebora, N., Parodi, A., Mihalovic, A., Ivkovic, M., Dekic, L., van Verseveld, W., Nuissier, O., Ducrocq, V., D’Agostino, D., Galizia, A., Danovaro, E., Clematis, A., 2015. Hydrometeorological multi-model ensemble simulations of the 4 November 2011 flash flood event in Genoa, Italy, in the framework of the DRIHM project. Nat. Hazards Earth Syst. Sci. 15, 537-555. https://doi.org/10.5194/nhess-15-537-2015

Hosking, J. R. M. 1990. L-Moments: Analysis and Estimation of Distributions Using Linear Combinations of Order Statistics. J. R. Stat. Soc. Ser. B 52, 105-124. https://doi.org/10.1111/j.2517-6161.1990.tb01775.x

Insua-Costa, D., Miguez-Macho, G., Llasat, M.C. 2019. The role of remote and local moisture sources in the two famous 1982 Western Mediterranean torrential rainfall episodes. Hydrol. Earth Syst. Sci. 23, 3885-3900, https://doi.org/10.5194/hess-23-3885-2019.

IPCC. 2012. Managing the risks of extreme events and disasters to advance climate change adaption (SREX) Intergovernmental Panel on Climate Change, Cambridge University Press, 582 pp., Cambridge.

IPCC. 2014. AR5 Synthesis Report: Climate Change 2014. https://www.ipcc.ch/report/ar5/syr/ 
IPCC. 2018. Global warming of 1.5. https://www.ipcc.ch/sr15/

Jacob, D., Petersen, J., Eggert, B., Alias, A., Bøssing, O., Bouwer, L. M., Braun, A., Colette, A., Georgopoulou, E., Gobiet, A., Menut, L., Nikulin, G., Haensler, A., Kriegsmann, A., Martin, E., Meijgaard, E. V., Moseley, C., Pfeifer, S. 2014. EURO-CORDEX: new high-resolution climate change projections for European impact research. Regional Environmental Change 35, 563-578. https://doi.org/10.1007/s10113013-0499-2

Jansà, A., Alpert, P., Arbogast, P., Buzzi, A., Ivancan-Picek, B., Kotroni, V., Llasat, M.C., Ramis, C., Richard, E., Romero, R., Speranza, A. 2014. MEDEX: a general overview. Nat. Hazards Earth Syst. Sci. 14, $1965-$ 198. https://doi.org/10.5194/nhess-14-1965-2014

Kendall, M. G. 1975. Rank Correlation Methods, Fourth Edition. Charles Griffin, London.

Koenker, R., Basset, B. G. 1978. Regression quantiles. Econometrica 46, 33-50.

Kreibich, H., Di Baldassarre, G., Vorogushyn, S., Aerts, J. C. J. H., Apel, H., G.T. Aronica, Arnbjerg-Nielsen, K., Bouwer, L.M., Bubeck, P., Caloiero, T., Chinh, D.T., Cortès, M., Gain, A.K., Giampá, V., Kuhlicke, C., Kundzewicz, Z.B., Llasat, M.C., Mård, J., Matczak, P., Mazzoleni, M., Molinari, D., Dung, N.V., Petrucci, O., Schröter, K., Slager, K., Thieken, A.H., Ward, P.J., Mertz, B. 2017. Adaptation to flood risk - results of international paired flood event studies. Earth's Future 5, 953-965, https://doi.org/10.1002/2017EF000606

Llasat, M.C., Barriendos, M., Barrera, A., Rigo, T. 2005. Floods in Catalonia (NE Spain) since the 14th century. Climatological and meteorological aspects from historical documentary sources and old instrumental records. Journal of Hydrology 313, 32-47 https://doi.org/10.1016/j.jhydrol.2005.02.004

Llasat, M.C., Llasat-Botija, M., López, L. 2009. A press database on natural risks and its application in the study of floods in northeastern Spain. Nat. Hazards Earth Syst. Sci., Sci. 9, 2049-2061. https://doi.org/10.5194/nhess-9-2049-2009

Llasat, M.C., Llasat-Botija, M., Petrucci, O., Pasqua, A.A., Rosselló, J., Vinet, F., Boissier, L. 2013a. Towards a database on societal impact of Mediterranean floods in the framework of the HYMEX project. Nat. Hazards Earth Syst. Sci. 13, 1-14. https://www.doi.org/10.5194/nhess-13-1-2013

Llasat, M.C., Llasat-Botija, M., Petrucci, O., Pasqua, A.A., Rosselló, J., Vinet, F., Boissier, L. 2013b. Floods in the North-Western Mediterranean Region: presentation of the HYMEX database and comparison with pre-existing global databases. La Houille Blanche 1, 5-9. https://doi.org/10.1051/lhb/2013001

Llasat, M.C., R. Marcos, M. Llasat-Botija, J. Gilabert, M. Turco, P. Quintana, 2014. Flash flood evolution in North-Western Mediterranean. Atmospheric Research 149, 230-243. https://doi.org/10.1016/j.atmosres.2014.05.024

Llasat, M.C., Marcos, R., Turco, M., Gilabert, J., Llasat-Botija, M. 2016a. Trends in flash flood events versus convective precipitation in the Mediterranean region: The case of Catalonia. Journal of Hydrology, 541, 24-37. https://doi.org/10.1016/j.jhydrol.2016.05.040

Llasat, M.C., Cortés, M., Falcón, LI., Gilabert, J., Llasat-Botija, M., Marcos, R., Martín Vide, J.P., Turco, M. 2016b. A multifactorial analysis of flood variability in the Metropolitan Area of Barcelona. Proceedings International Conference on Urban Risks, ICUR 2016. Lisbon.

Llasat, M.C., del Moral, A., Cortés, M., Rigo, T., in rev. Convective precipitation trends in the Spanish Mediterranean region. Accepted. Atmospheric Research

Mangini, W., Viglione, A., Hall, J., Hundecha, Y., Ceola, S., Montanari, A., Rogger, M., Salinas, J.L., Borzì, I., Parajka, J. 2018. Detection of trends in magnitude and frequency of flood peaks across Europe. Hydrological Sciences Journal 63(4), 493-512. https://doi.org/10.1080/02626667.2018.1444766

Mann, H. B. 1945. Non-parametric tests against trend. Econometrica 13, 163-171.

Martín, A., Romero, R., Homar, V., de Luque, A., Alonso, S., Rigo, T., Llasat, M.C., 2007. Sensitivities of a flash flood event over Catalonia: a numerical analysis. Mon. Weather Rev. 135, 651-669. https://doi.org/10.1175/MWR3316.1 
MedECC, 2019. Risks associated to climate and environmental changes in the Mediterranean region. Preliminary assessment by the MedECC Network Science-policy interface. https://www.medecc.org/medecc-bookletisk-associated-to-climate-and-environmental-changes-in-the-mediterranean-region/

MedECC, 2020. Climate and Environmental Change in the Mediterranean Basin - Current Situation and Risks for the Future. In: W. Cramer, J. Guiot, K. Marini (Eds.). First Mediterranean Assessment Report Union for the Mediterranean, Plan Bleu, UNEP/MAP, Marseille, France, 600 pp.

Mediero, L., Santillán, D., Garrote, L., Granados, A. 2014. Detection and attribution of trends in magnitude, frequency and timing of floods in Spain, J. Hydrol. 517, 1072-1088. https://www.doi.org/10.1016/j.jhydrol.2014.06.040.

Merz, B., Vorogushyn, S., Uhlemann, S., Delgado, J., Hundecha, Y. 2012. More efforts and scientific rigour are needed to attribute trends in flood time series. Hydrol. Earth Syst. Sci. 16, 1379-1387. https://doi.org/10.5194/hess-16-1379-2012

Montanari, A. 2012. Hydrology of the Po River: looking for changing patterns in river discharge. Hydrol. Earth Syst. Sci. 16, 3739-3747. https://doi.org/10.5194/hess-16-3739-2012

Nakamura, I., Llasat, M.C. 2017. Policy and systems of flood risk management: a comparative study between Japan and Spain Natural. Hazards 87, 919. https://doi.org/10.1007/s11069-017-2802-x

O’Neill, B.C., Kriegler, E., Riahi, K., Ebi, K. L., Hallegatte, S., Carter, T.R., Mathur, R., van Vuuren, D.P. 2014. A new scenario framework for climate change research: the concept of shared socioeconomic pathways. Climatic change 122, 387-400. https://doi.org/10.1007/s10584-013-0905-2

Papagiannaki, K., Lagouvardos, K., Kotroni, V., Bezes, A. 2015. Flash flood occurrence and relation to the rainfall hazard in a highly urbanized area. Nat. Hazards Earth Syst. Sci. 15, 1859-1871, https://doi.org/10.5194/nhess-15-1859-2015.

Pastor, F., Valiente, J.A., Khodayar, S., 2020. A Warming Mediterranean: 38 Years of Increasing Sea Surface Temperature. Remote Sens. 12, 2687. https://doi.org/10.3390/rs12172687

Petrucci, O., Aceto, L., Bianchi, C., Bigot, V., Brázdil, R., Pereira, S., Kahraman, A., Kılıç, O., Kotroni, V., Llasat, M.C., Llasat-Botija, M., Papagiannaki, K., Pasqua, A.A., Řehoř, J., Rossello Geli, J., Salvati, P., Vinet, F., Zêzere, J.L. 2019. Flood Fatalities in Europe, 1980-2018: Variability, Features, and Lessons to Learn. Water 11, 1682. https://doi.org/10.3390/w11081682

Piras, M., Mascaro, G., Deidda, R., Vivoni, E. R. 2016. Impacts of climate change on precipitation and discharge extremes through the use of statistical downscaling approaches in a Mediterranean basin. Sci. Total Environ. 543, 952-964. https://doi.org/10.1016/j.scitotenv.2015.06.088

Quintana-Seguí, P., Le Moigne, P., Durand, Y., Martin, E., Habets, F., Baillon, M., Canellas, C., Franchisteguy, L., Morel, S. 2008. Analysis of Near-Surface Atmospheric Variables: Validation of the SAFRAN Analysis over France. J. Appl. Meteorol. Clim. 47, 92-107. https://doi.org/10.1175/2007JAMC1636.1

Renard, B., Lang, M., Bois, P., Dupeyrat, A., Mestre, O., Niel, H., Sauquet, E., Prudhomme, C., Parey, S., Paquet, E., Neppel, L., Gailhard, J. 2008. Regional methods for trend detection: assessing field significance and regional consistency. Water Resour. Res. 44 (8). https://doi.org/10.1029/2007WR006268

Romero, R., Ramis, C., Guijarro, J.A., 1999. Daily rainfall patterns in the Spanish Mediterranean area: An objective classification. Int. J. Climatol. 19, 95-112. https://doi.org/10.1002/(SICI)10970088(199901)19:1<95::AID-JOC344>3.0.CO;2-S

Sen, P. K. 1968. Estimates of the regression coefficient based on Kendall's tau. J. Am. Stat. Assoc. 63, 1379-1389.

Thielen, J., Bartholmes, J., Ramos, M.H., de Roo, A. 2009. The European Flood Alert System - Part 1: Concept and development. Hydrol. Earth Syst. Sci. 13, 125-140, https://doi.org/10.5194/hess-13-125-2009

Tramblay, Y., Hertig, S. 2018. Modelling extreme dry spells in the Mediterranean region in connection with atmospheric circulation. Atmospheric Research 202, 40-48, https://doi.org/10.1016/j.atmosres.2017.11.015

Tramblay, Y., Somot, S. 2018. Future evolution of extreme precipitation in the Mediterranean. Climatic Change 151, 289-302. https://doi.org/10.1007/s10584-018-2300-5 
Tramblay, Y., Mimeau, L., Neppel, L., Vinet, F., Sauquet, E. 2019. Detection and attribution of flood trends in Mediterranean basins. Hydrol. Earth Syst. Sci. 23, 4419-4431. https://doi.org/10.5194/hess-23-44192019.

Turco, M., Rosa-Cánovas, J.J., Bedia, J., Jerez, S., Montávez, J.P., Llasat, M.C., Provenzale, A. 2018. Exacerbated fires in Mediterranean Europe due to anthropogenic warming projected with nonstationary climate-fire models. Nature Communications 9, 3821. https://doi.org/10.1038/s41467-018-06358-z

UNISDR 2009. Global Assessment Report on Disaster Risk Reduction 2009. Geneva, Switzerland. https://www.undrr.org/publication/global-assessment-report-disaster-risk-reduction-2009

UNDRR 2020. Hazard. Definition and classification review. Technical Report. 87 pp. https://www.undrr.org/publication/hazard-definition-and-classification-review

Vinet, F., Bigot, V., Petrucci, O., Papagiannaki, K., Llasat, M.C., Kotroni, V. Boissier, L., Aceto, L., Grimalt, M., Llasat-Botija, M., Pasqua, A.A., Rossello, J., Kılıç, Ö., Kahraman, A., Tramblay, Y. 2019. Mapping Flood-Related Mortality in the Mediterranean Basin. Results from the MEFF v2.0 DB. Water 11, 2196. https://doi.org/10.3390/w11102196 